\title{
The effectiveness of new Technology Planning and its Implementation in Central Coalfields Ltd. A Case Study.
}

\author{
${ }^{1}$ Anand Pd. Sinha, ${ }^{2}$ Dr. P. C. Jha \\ ${ }^{1}$ Associate Lecturer, ${ }^{2}$ Assistant Professor,Department of Management, BIT Mesra, Ranchi
}

\begin{abstract}
With the rising complexity and globalization phenomenon, technology has gained overriding objective in the fast changing competitive environment. In the contemporary business environment latest technology is imperative for maintaining quality standards in order to remain in the business. There are two aspect of technology. The first one is the selection of appropriate \& suitable technology and the second aspect is the effective management of the new technology. Today simply taking up of new technologies is not difficult task due to innumerable alternatives available both indigenously as well as internationally. However the second aspect needs to be focused to understand the effective management of technology to capitalize it to the maximum.

At the outset the paper attempts to focus on the coal mining industries a vital sector of Indian economy. Energy security is the prime concern of Indian economy which is distressing Indian industries a lot. Indian Coal mining is still far behind in global standards inspite of implementation and use of best technologies. The problem lies in the implementation \& its effective management. The way in which internal planning and implementation processes are managed could greatly influence the outcome of new technology. Technology implementation and planning refers to extent how the organization has strategically designed the deployment of new technology(s) prior to its implementation. The processes incorporated within this design influence the overall effectiveness of technology deployment and utilization. This study explores the strategies and methods adopted in a Coal mining industry for effective management of new technology and its implementation. For this purpose one of the public sector organization namely Central Coalfields limited, located at Ranchi, Jharkhand is being selected. The study pertains to find out the reasons for low productivity of coal in seven sites of CCL, These are Piparwar OC, Ashoka OC, KDH OC, Rajrappa OC, Urimari OC, Amlo OC, Jharkhand OC.(OCOpen Cast Mines.)
\end{abstract}

Key words: Technology Management, Opencast Coal Mining in Central Coalfields Ltd. Effective management of new technology and its implementation.

\section{Research objective}

1. To understand the role of effective management of technology in CCL.

2. To find out the influencing factors needed for effective management of technology in open cast coal mining.

Hypothesis of the study

$\mathbf{H}_{\mathbf{0}}=$ Technology is not a panacea for productivity enhancement rather Effective management of technology is important to become more productive.

H1 = Technology is important for enhancing the productivity but lack of effective management of technology can reduce the productivity

The study identified the following important parameters which was relevant for the study for effective management of new technology.

1 Management of Technical Skills

2 Managing Training Needs

3. Managing Financial recourses

4 Managing Safety requirements

\section{Research Methodology}

A survey was conducted to find out the various reasons of low productivity in opencast coal mines in CCL even after the adoption of technology. Thereafter certain parameters were being identified and were incorporated in the form of question in the questionnaire. The respondents were selected through convenient sampling in the opencast mines. The target sample population was 385 from top and middle level of management. The study is based on descriptive method of research. 


\section{Introduction}

Technology Management "links engineering, science, and management disciplines to plan to develop and to implement technological capabilities to shape and accomplish the strategic and operational objectives of an organization" Millett Stephen. M(1990). Technology management has its roots in Strategic Management, Engineering Management, Innovation Management and R \& D Management. (Ulhoi, 1996).

Management of technology focuses on the principles of strategy and organization involved in technology choices, guided by the purpose of creating value for investors. (Narayan.V.K,2002). Management of technology is an interdisciplinary field that integrates science, engineering and management knowledge and practice. The focus is on technology as the primary factor in wealth creation, wealth creation involves more than just money. It may encompasses factors such as enhancement of knowledge, intellectual, capital, effective exploitation of resources, preservation of the natural environment and other factors that may contribute to raising the standard of living and quality of life. Managing technology implies managing the system that enables the creation, acquisition and exploitation of technology (Tsang, E.W.K., 1995). Management of technology encompasses two types of changes. "The process technology change and the product technology change".

Technological success has changed the life of everyone in the world and it has also changed the way coal mining companies explore and market coal (Christina Beach, Thielst, .(July 2007). In other words, the technologies have made a coal mining industry a high-technological affair that is equipped with all the necessary machinery for raise the productivity. Today in the dynamic business scenario the importance of the state of the art technology is observed and adopted for enhancing productivity. Almost every industrial sector today warrants for the best use of technology in order to remain competitive for sustainability (Friedman, T. L. 2005). The Indian coal sector presently is in the transition phase from traditional to the state of art technology.

Most of the technology adopted so far by CCL is almost imported and rely on its effective management. The researcher feels that the government coal mining industries lacks behind in the effective management of new technology and is not able to justify the return on investment. Technology is not a panacea for the lacking skills instead it is a tool that complements organizational abilities, allowing becoming more productive. Technology can cause as many problems as it solves.

Technology can improve the efficiency of the organization manifolds but lack of effective management of technology can defeat the entire purpose. The background of the research is based on the managerial issues related to the effective management of technology in Central Coal fields extracting coal which generates almost $40 \%$ of the energy requirement of the country. In CCL it has been studied that the adoptions of the state of art technology comprehend the present need however there lacks its effective management of new technology. It is true that the wrong choice of technology leads to dismal consequences affecting the overall health of the organization nonetheless the fact also lies in the effective management of the new technology. Indian coal industries have witnessed a series of technological changes but it is still struggling in extracting coal suitable for the domestic consumption rather depending on the imported coal. The technology can not be effective unless it has been supported by appropriate organizational changes as well as changes in human skills and training. Affectivity of a technology depends on effectively managed technology. In broader view there may be various factors which needs to be considered while implementation and effective management of new as well as existing technology. Technology implementation and planning refers to the extent in which the organization has strategically designed the deployment of its new technology(s) prior to its implementation.. The processes incorporated within this design have been cited to influence the overall effectiveness of technology deployment and utilization (Betz, Fredrick, 1987). Throughout the implementation process, effective management means supporting the project team, selecting the right technology, and designing and providing appropriate training. This will ensure that the new technology will complement existing processes and systems and will allow more productivity throughout. Today in the dynamic business scenario the importance of the state of the art technology is observed and adopted for enhancing productivity. Almost every industrial sector today warrants for the best use of technology in order to remain competitive for sustainability. The Indian coal sector presently is in the transition phase from traditional to the state of art technology. The coal sector is majorly under control of government under the aegis of CCL leading public sector mining industries. However the private player have entered into coal extraction and mining giving competition to central public sector in coal mining. At the outset it is prime concern for the government control mining industry to be competitive with quality production of coal through maximum utilization of the technology.

Most of the technology adopted so far by CCL is almost imported and rely on its effective management. This study focus on the problem encountered while managing of technology right from its (1) Adoption (2) Implementation (3) Productive utilization.

The researcher feels that the government coal mining industries lacks behind in the effective management of new technology and is not able to justify the return on investment. The technology cannot play itself it brings a change and it has to be supported by appropriate organizational changes as well as changes in human skills and training. It also brings innovation in a variety of field affecting human needs such as health environment, comfort, entertainment, communication, food etc. There is no denying the fact that the wrong 
choice of technology for a product, process can have serious implication on the health of the organization. Therefore assessment and evaluation with respect to its cost effectiveness, availability of raw material and skill availability needs to be established.

\section{Brief History of Coal Mining in India.}

Coal mining first set up in India in the year 1815. The private Companies began mining activities in the year 1850.Commercial coal mining, which began in India in the late 1700s, was primarily in private hands till 1971.The Government of India (GOI) nationalized the industry in 1972-73 with the objective of ensuring an orderly development of a sector that serves strategically important industries like power and steel. It was also felt that the sector needed to significantly improve on the technology for coal extraction and mining practices, and invest large sums of money in the development of new reserves-objectives that could be better served if the industry was under the direct control of the Government of India.. As a consequence of the nationalization process, coal was subject to pricing and distribution controls. While prices were determined on the basis of the formulae fixed by the Bureau of Industrial Costs and Prices (BICP), Linkage Committees consisting of representatives from the ministries of coal, power, steel, railways and others decided on the allocation among different consumers.

With the advent of Independence, the country embarked upon the 5-year development plans. At the beginning of the $1^{\text {st }}$ Plan, annual production went upto $33 \mathrm{Mt}$. During the $1^{\text {st }}$ Plan period itself, the need for increasing coal production efficiently by systematic and scientific development of the coal industry was being felt. Setting up of the National Coal Development Corporation (NCDC), a Government of India Undertaking in 1956 with the collieries owned by the railways as its nucleus was the first major step towards planned development of Indian Coal Industry. Along with the Singareni Collieries Company Ltd. (SCCL) which was already in operation since 1945 and which became a Government company under the control of Government of Andhra Pradesh in 1956, India thus had two Government coal companies in the fifties. SCCL is now a joint undertaking of Government of Andhra Pradesh and Government of India sharing its equity in 51:49 ratio.

Nationalization of Coal Mines - Right from its genesis, the commercial coal mining in modern times in India has been dictated by the needs of the domestic consumption. On account of the growing needs of the steel industry, a thrust had to be given on systematic exploitation of coking coal reserves in Jharia Coalfield. Adequate capital investment to meet the burgeoning energy needs of the country was not forthcoming from the private coal mine owners. Unscientific mining practices adopted by some of them and poor working conditions of labour in some of the private coal mines became matters of concern for the Government. On account of these reasons, the Central Government took a decision to nationalize the private coal mines. The nationalization was done in two phases, the first with the coking coal mines in 1971-72 and then with the non-coking coal mines in 1973. In October 1971, the Coking Coal Mines (Emergency Provisions) Act, 1971 provided for taking over in public interest of the management of coking coal mines and coke oven plants pending nationalization. This was followed by the Coking Coal Mines (Nationalization) Act, 1972 under which the coking coal mines and the coke oven plants other than those with the Tata Iron \& Steel Company Limited and Indian Iron \& Steel Company Limited, were nationalized on 1.5.1972 and brought under the Bharat Coking Coal Limited (BCCL), a new Central Government Undertaking. Another enactment, namely the Coal Mines (Taking Over of Management) Act, 1973, extended the right of the Government of India to take over the management of the coking and non-coking coal mines in seven States including the coking coal mines taken over in 1971. This was followed by the nationalization of all these mines on 1.5.1973 with the enactment of the Coal Mines (Nationalization) Act, 1973.

\section{Central Coalfields Ltd}

The Coal has come a long way to occupy pride and place in the industrial economy of the country as one of the prime source of energy. On $31^{\text {st }}$ January 1973, non coking coal mines was taken over by the Government and Coal Mines Authority Limited (CMAL) was formed-with four operating divisions and NCDC because one of the divisions namely the Central Division of CMAL. In 1975, further reorganization of coalmines resulted in the incorporation of Coal India Limited as the holding company. It is the second largest corporate employer in the world providing employment to 6,60,000 people and has a board of directors headed by full time chairman who is the chief executive of the company. Coal India Limited and its subsidiaries produce and supply coal \& coal products to core sectors like Steel, Power, Cement, Fertilizers, Defense, Railways, and other coal based industries and to domestic consumers. It is an almost monopoly coal producing and selling enterprise of the Government.

CIL has eight subsidiary companies. They are: -

$>\quad$ Eastern Coalfields Limited (ECL)

$>\quad$ Bharat Coking Coal Limited (BCCL) 
The effectiveness of new Technology Planning and its Implementation in Central Coalfields Ltd.

Central Coalfields Limited (CCL)

Northern Coalfields Limited (NCL)

Western Coalfields Limited (WCL)

South Eastern Coalfields Limited (SECL)

Mahanadi Coalfields Limited (MCL)

Central Mine Planning and Design Institute Limited (CMPDIL)

The central division of CMAL was converted into individual coal company named Central Coalfields Limited, a subsidiary of CIL. Central Coalfields Limited is engaged in mining of coal, beneficiation of medium coking and non-coking coal, supply and distribution of coal, and development of new coalfields. The operations of the company are spread over the coal reserve areas in various districts of the state of Jharkhand with its headquarters situated in the capital city of Ranchi and have a workforce of 80,000 plus employees on its rolls. There are 15 different working areas under this company. These are: - Barkakana, Sayal, Argada, NK ajhara, Piperwar, Rajrappa, Kuju, Hazaribagh, Bokaro \& Kargali, Giridih, Dhori, Kathara, Bokaro, Washeries, and Central Repair Workshop.

At present, CCL is the owner of 58 operating mines (21 Underground + 37 Open Cast), 7 washeries (4 Coking, Kathara, Rajrappa, Kedla \& Sawang throughput capacity of 9.35 MTPA + 3 Non-Coking, Piparwar, Kargali \& Gidi throughput capacity of 11.72 MTPA \& 6 workshops (1 Central Workshop (ISO 9001) at Barkakana and 5 Regional Repair/Workshops (3 w/s are ISO 9001) at Jarandih, Tapin North, Dakra, Giridih \& Bhurkunda. The total command area of the coalfield is about $2600 \mathrm{Sq} \mathrm{Km}$ spread of 6 major coalfields all falling within the mineral rich state of Jharkhand.(source : Central Coalfields Ltd, Ranchi)

\section{Effective Management of Technology.}

Technology is not a panacea for the lacking skills instead it is a tool that complements organizational abilities, allowing becoming more productive (Christina Beach, Thielst ).Technology can cause as many problems as it solves. Once it is determined that new technology is indeed the answer to organizational needs, the organization can move on to the next step. Technology can improve the efficiency of the organization manifolds but lack of effective management of technology can defeat the entire purpose. The background of the research is based on the managerial issues related to the effective management of technology in Central Coal fields extracting coal which generates almost $40 \%$ of the energy requirement of the country. It is believed that energy production through natural resources is oil , Gas and Coal the longevity of production ever be guaranteed through coal because of the reserves for almost 120 years presently. Presently CCL is managing, Barkakana, Sayal, Argada, NK Ajhara, Piperwar, Rajrappa, Kuju, Hazaribagh, Bokaro \& Kargali, Giridih, Dhori, Kathara, Bokaro, Washeries, and Central Repair Workshop.

In the context of the present economic liberalization, globalization and free market this study assumes greater importance as management of technology will be hallmark of the policy of nation if we wish to make our presence felt in the new world market.

This study will be in a position to give a comprehensive view on the factors, which influence the technology management. In CCL it has been studied that the adoptions of the state of art technology comprehend the present need however there lacks its effective management of new technology. The choice of the technology based suits the organizational needs none the less there is lacuna for best training of the end user of the technology. Moreover employees are also rigid for continual changes lacking versatility. The status quo reveals out few interesting facts such as majority of the working population have an educational gap of almost twenty years behind due to non- recruitment policies of fresh engineers since 1991. Even the top management is apprehensive in the decision making process for implementation due to bureaucratic environment of the management structure of CCL.

\section{Need For The Study:}

Energy crisis in India is looming large due to high price of petroleum all over the world and India coal mining industries is failing to meet the national demand. Imports of coal are increasing as the total effective coal import duties in India have been slashed drastically, which has made imported coal cheaper in terms of Rs./calorie i.e. the money paid for the heat value. In 1992-93 the total effective import duty was $85 \%$ and 35\% for non-coking and coking coal respectively, which has been brought down to $32.5 \%$ and $9.72 \%$ in $2009-010$.

- Imported coal is available at a lesser price. The increasing trend of coal imports require Indian coal industry to be price competitive and has to find out ways to control costs and improve productivity.

- There is more emphasis of the Government towards generating own funds to meet the financial requirements.

- Back-door privatization inspite of acquisition of New Technology. 
The effectiveness of new Technology Planning and its Implementation in Central Coalfields Ltd.

The above mention points are major threats and weakness which warrants for investigator for poor quality as well as law quantity production of coal. The study pertains to explore the issues related to above problems due to lack of effective management of technology. These could be other reasons which is pathing the Central Coalfields Ltd, behind in coal production, however the study primarily focuses on the issues pertaining to relate to management of technology in three phases is

$>$ Evaluation for need of technology and latest on adoption of New Technology.

$>$ Sourcing and installation of Technology

$>$ Productivity from the installed new technology.

CCL has installed some technology for raise the productivity in their open cast mining as follows;

- Installation and commissioning of Mobile Inpit Coal Crushing and Conveying in Piparwar OCP (6.5 MTY)

- Installation and commissioning of 10 cu.mtrs. and 25 cu.mtrs. Shovels and 85 T Dumpers in different Open Cast mines.

- Introduction of Surface Minor in Ashoka Expansion

- Installation of Rapid Loading System in Dhori Colliery.

- 3.0 MTY Rajrappa OCP has been commissioned with a pithead coking coal beneficiation plant.

Production Report; - CCL- Production at seven sites

\begin{tabular}{|c|c|c|c|c|c|c|c|c|c|}
\hline \multicolumn{10}{|c|}{ Table No: 1} \\
\hline \multirow[t]{2}{*}{ Sl No } & \multirow[t]{2}{*}{ Project } & \multicolumn{2}{|c|}{$\begin{array}{c}2007-2008 \\
\text { (Mt) }\end{array}$} & \multicolumn{2}{|c|}{ 2008-2009(Mt) } & \multicolumn{2}{|c|}{ 2009-2010(Mt) } & \multicolumn{2}{|c|}{ 2010-2011(Mt) } \\
\hline & & Target & Actual & Target & Actual & Target & Actual & Target & Actual \\
\hline 1 & $\begin{array}{c}\text { Piparwar } \\
\text { OC }\end{array}$ & 10.00 & 9.00 & 10.00 & 9.00 & 10.00 & 9.51 & 9.75 & 9.00 \\
\hline 2 & $\begin{array}{c}\text { Ashoka } \\
\text { OC }\end{array}$ & 6.5 & 6.30 & 9.50 & 7.10 & 9.00 & 7.60 & 8.75 & 8.030 \\
\hline 3 & $\mathrm{KDH} \mathrm{OC}$ & 4.5 & 4.01 & 3.50 & 3.14 & 3.70 & 3.51 & 3.50 & 3.451 \\
\hline 4 & $\begin{array}{c}\text { Rajrappa } \\
\text { OC }\end{array}$ & 3.00 & .85 & 1.20 & 1.00 & 1.25 & 1.10 & 1.1 & 1.101 \\
\hline 5 & $\begin{array}{c}\text { Jharkhand } \\
\text { OC }\end{array}$ & 1.0 & .81 & 0.85 & .92 & 0.85 & .60 & 0.95 & .606 \\
\hline 6 & $\begin{array}{c}\text { Urimari } \\
\text { OC }\end{array}$ & 2.0 & 2.33 & 2.00 & 2.44 & 2.25 & 1.51 & 2.50 & 2.039 \\
\hline 7 & Amlo OC & 2.50 & 1.43 & 1.20 & 2.81 & 2.00 & 3.12 & 3.00 & 2.041 \\
\hline
\end{tabular}

(Source: Central Coalfields Ltd, Ranchi)

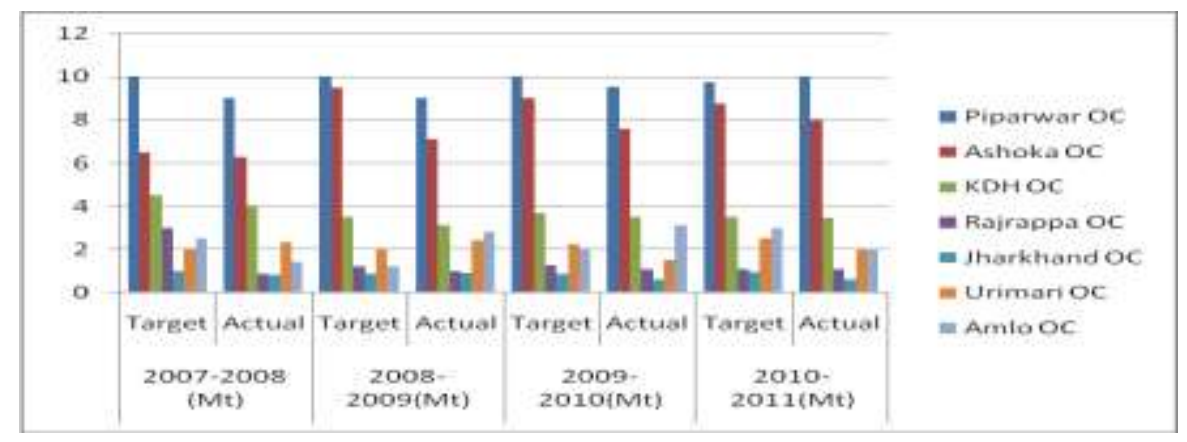

The actual production was less than the targeted production of these opencast mines. The main issue of the problem encounter is environmental impact and also managerial issue for lacking effective management for growing the production. The productivity of opencast mines is low because of misuse and non-availability of materials, scarcity of power, shortage of explosive, defective layouts and poor working conditions are the causes of low productivity. Poor planning and lack of management training are also two drawbacks affecting productivity. The following are main factors of decreasing the productivity in Central Coal Fields, which are not achieving the targeted production 
The effectiveness of new Technology Planning and its Implementation in Central Coalfields Ltd.

1.Internal and 2. External problems.

The internal problems are:-

i) Design of the mine.

ii) Technology employed

iii) Shortage of skilled and statutory personnel and

iv) Maintenance of equipments.

2. External problems are: -

i) Power

ii) Explosive

iii) Absenteeism

iv) Labour unrest

v) Law and order

vi) Wagon availability

vii) Land acquisition

viii) Lack of capital investment.

ix) Environmental Issue.

\section{Analysis of Data:}

Primary data was gathered from CCL headquarters at Ranchi including Surrounding Coalfields open cast coal mines and the Central Mine Planning and Design Institute, Ranchi, through questionnaires and interviews in order to understand the problems encountered towards management of technology. Various key personnels were contacted from various departments of CCL and CMPDIL, as well as, from the coalmines located in the state of Jharkhand.

\section{Over all data of CCL.CPMDI and seven open cast mines.}

Table No: 2

\begin{tabular}{|c|c|c|c|c|c|c|c|c|c|c|c|}
\hline \multirow{7}{*}{$\begin{array}{l}\text { Effective } \\
\text { managemen } \\
\text { t of } \\
\text { technology } \\
\text { is important } \\
\text { for } \\
\text { enhanceme } \\
\text { nt of } \\
\text { productivity } \\
\text { in open cast } \\
\text { coal } \\
\text { mining? }\end{array}$} & \multirow{2}{*}{$\begin{array}{l}\text { Response } \\
\text { Scale }\end{array}$} & \multirow{2}{*}{$\begin{array}{l}\text { CCL } \\
(\mathrm{N}=9 \\
1) \\
\% \text { (Fre } \\
\text { q) }\end{array}$} & \multirow{2}{*}{$\begin{array}{l}\text { CMPD } \\
\text { I } \\
\text { (N=69) } \\
\% \text { (Freq } \\
\text { ) }\end{array}$} & \multicolumn{7}{|c|}{ Open Cast Mines } & \multirow{2}{*}{$\begin{array}{l}\text { Total } \\
(\mathrm{N}=38 \\
5) \\
\% \\
\text { (Freq) }\end{array}$} \\
\hline & & & & $\begin{array}{l}\text { Piparw } \\
\text { ar } \\
(\mathrm{N}=30) \\
\%( \\
\text { Freq) }\end{array}$ & $\begin{array}{l}\text { Ashoka } \\
(\mathrm{N}=40) \\
\% \text { (Freq } \\
\text { ) }\end{array}$ & $\begin{array}{l}\mathrm{KDH} \\
(\mathrm{N}=35) \\
\%(\text { Fre } \\
\text { q) }\end{array}$ & $\begin{array}{l}\text { Urimari } \\
(\mathrm{N}=30) \\
\% \text { (Freq } \\
\text { ) }\end{array}$ & $\begin{array}{l}\text { Rajrapp } \\
\text { a } \\
(\mathrm{N}=35) \\
\%( \\
\text { Freq) }\end{array}$ & $\begin{array}{l}\text { Amlo } \\
(\mathrm{N}=30) \\
\%(\text { Freq } \\
)\end{array}$ & $\begin{array}{l}\text { JHOC } \\
(\mathrm{N}=25) \\
\%(\text { Freq } \\
)\end{array}$ & \\
\hline & $\begin{array}{l}\text { 1-Not } \\
\text { Important }\end{array}$ & & & & & & & & & & \\
\hline & $\begin{array}{l}2- \\
\text { SomeWh } \\
\text { at } \\
\text { important }\end{array}$ & & & & & & & & & & \\
\hline & $\begin{array}{l}\text { 3- } \\
\text { Can'tSay, }\end{array}$ & & & & & & & & & & \\
\hline & $\begin{array}{l}4- \\
\text { Important }\end{array}$ & $\begin{array}{l}39.6(3 \\
6)\end{array}$ & $\begin{array}{l}21.7(15 \\
)\end{array}$ & $30(9)$ & $27.5(11$ & $20(7)$ & $30(9)$ & $40(14)$ & $40(12)$ & $48(12)$ & $\begin{array}{l}32.5(1 \\
25)\end{array}$ \\
\hline & $\begin{array}{l}\text { 5-Highly } \\
\text { important }\end{array}$ & $\begin{array}{l}60.4(5 \\
5)\end{array}$ & $\begin{array}{l}78.3(54 \\
)\end{array}$ & $70(21)$ & $\begin{array}{l}72.5(29 \\
)\end{array}$ & $80(28)$ & $70(21)$ & $60(21)$ & $60(18)$ & $52(13)$ & $\begin{array}{l}67.5(2 \\
60)\end{array}$ \\
\hline
\end{tabular}

Graph:- Table no-2

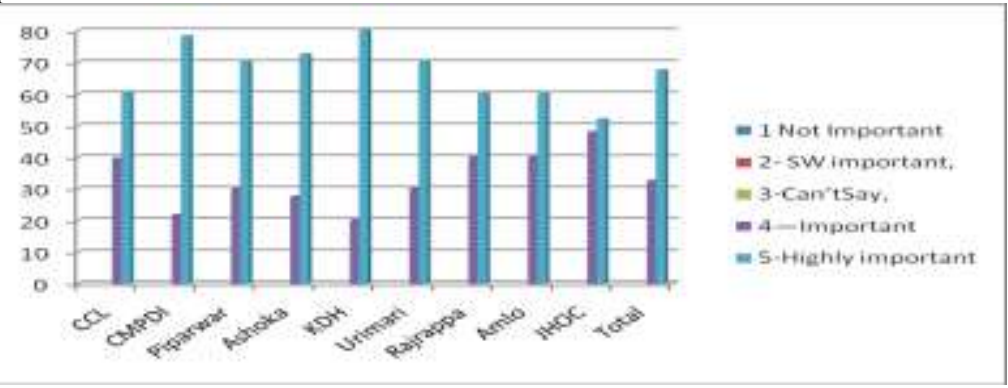


The effectiveness of new Technology Planning and its Implementation in Central Coalfields Ltd. Frequency table of responses of three units.

Table No: 3

\begin{tabular}{|c|c|c|c|c|}
\hline \multirow{2}{*}{$\begin{array}{l}\text { Response } \\
\text { Scale }\end{array}$} & \multicolumn{3}{|c|}{ Units } & \multirow[b]{2}{*}{ Total } \\
\hline & OC & $\mathrm{CCL}$ & CMPDI & \\
\hline \multirow[t]{2}{*}{ Important } & 74 & 36 & 15 & 125 \\
\hline & $32.9 \%$ & $39.6 \%$ & $21.7 \%$ & $32.5 \%$ \\
\hline \multirow{2}{*}{$\begin{array}{l}\text { Highly } \\
\text { important }\end{array}$} & 151 & 55 & 54 & 260 \\
\hline & $67.1 \%$ & $60.4 \%$ & $\mathbf{7 8 . 3 \%}$ & $67.5 \%$ \\
\hline Total & 225 & 91 & 69 & 385 \\
\hline
\end{tabular}

OC : Open Cast Mines, CCL: Central Coalfields Ltd, CPMDI: Central Mine Planning Design Institute Ltd

Table No: 4

\begin{tabular}{|l|r|r|r|}
\hline \multicolumn{4}{|c|}{ Chi-Square Tests } \\
\hline & \multicolumn{1}{|c|}{ Value } & df & $\begin{array}{c}\text { Asymp. Sig. (2- } \\
\text { sided) }\end{array}$ \\
\hline Pearson Chi-Square & $5.728^{\mathrm{a}}$ & 2 & .057 \\
\hline Likelihood Ratio & 5.928 & 2 & .052 \\
\hline Linear-by-Linear Association & 1.374 & 1 & .241 \\
\hline $\mathrm{N}$ of Valid Cases & 385 & & \\
\hline $\begin{array}{l}\text { a. } 0 \text { cells }(.0 \%) \text { have expected count less than 5. The minimum expected count is } \\
22.40 .\end{array}$ \\
\hline
\end{tabular}

Responses given by CCL, CMPDI, and their open cast coal mines, Effective Management of technology is highly important which is overall $67.5 \%$ as shown in table no 2.But After clubbing all the seven sites of open cast mines they are agreed to effective management of technology is necessary to enhance production which is $67.1 \%$ and also CCL is 60.4 and CMPDI is 78.3 as shown in table no 3. After calculating the Chi Square test the value is 5.728, degree of freedom is 2 and significance level is .057 as shown in table no 4 , which is greater than the tabular value of Chi-Square .05 as confidence level is $95 \%$. So it means that the output result is not significant, hence the null hypothesis is accepted. Hence it may be concluded that once technology has been introduced in the open cast coal mining, it needs to be managed effectively. So Technology is not only for enhance the production rather effective management of technology may play to vital role to enhance the productivity. This may increase productivity and hosts of other benefit may also apply.

\section{Conclusion:-}

During the course of the research study, the researcher has been exposed to various trends and practices related to the management of technology in a large public sector organization. The value addition in thoughts and concepts acquired in the process of overall analysis of the data collected, interactions through interviews, survey of literature, and personal observations have enabled the researcher to make certain suggestions and recommendations that can have a significant contribution towards enhancing the effectiveness of new technology planning and its implementation in Central Coalfields Ltd. Maximum utilization of manpower is the first requirement of improving productivity. Due to frequent delays rest and other personal need of the workers only $50 \%$ of the shift time is utilized in a mine. Reasons for time lost in job allocation, to make the face ready, on-availability of coal tubes, long haulage stoppage etc. should be given special attention. Another aspect to make the safest and most effective use of the various inputs used in the process of mining coal. Before drawing up any scheme, work sampling, time and method study technique should be applied to assess the workload of men and materials to determine their efficiencies and pinpoint the bottlenecks of existing operation. For any significant improvement in productivity and safety is it quickening the pace of mechanization. The scheme should be drawn after careful studies of all the available data previous planning coal reserve etc.ensuring that to provide $20-25 \%$ excess of the target. To achieve the target the most effective use of the various inputs should be considered. The environment conditions have a profound mental influence on the efficiency of workers; ventilation, temperature, dustiness, lighting, humidity, roof, control etc are important factors which affect productivity. 
The effectiveness of new Technology Planning and its Implementation in Central Coalfields Ltd.

The following factors will require serious thinking-

1. Planning- Availability of men, machinery, materials and money in time is the first necessity to achieve a definite production target.

2. Incentive- Fresh incentive should be introduced from time to time to keep up the enthusiasm of workers.

3. Management Training-Managerial staff should undergo some management training for smooth proper and efficient working of the same. It should arrange the vocational training for worker and give the theoretical as well as demonstration until they operate the machine.

4. Workers Participation- Poor management, labour relation no work reward unhealthy environment conditions lower production. Effective workers participation in management and involvement of workers with work process can provide incentives for work and should have harmonious relationship with the top as well as lower level management.

[1] Annual Plan of Central Coalfields Ltd.2009-2010

[2] Aragyaswamy. Kamala and Yasai-Ardekani. Masoud(1997) "Organizational Turnaround: Understanding the Role of Cutbacks, Efficiency, Improvements and Investment in technology"-IEEE Transactions on Engineering Management.Vol.44, No.1, Feb1997.

[3] Betz,Fredrick,1987, Managing Technology, Prentice Hall, Englewood Cliffs, New Jersey,P.27

[4] Christina Beach, Thielst, .(July 2007). Effective management of technology implementation.

[5] Collier, D. (1985). Linking business and technology to market. Harvard Business Review. March-April 1981. Vol 59, No. 2.

[6] Chatterjee. A.K(2001) “A Case Study of Technology Acquisition and Some Thoughts on Technology Evaluation”- Proceedings of the 2001 National Seminar on Technology Management, Indian National Academy of Engineering.

[7] Friedman, T. L. 2005 Effective management of technology implementation.

[8] Ghatak.S(1990) "A study of Mine management legislation and general safety." Coalfields Publishers, Asansol.

[9] Joshi(2001).B, "Management of Technological Change in the Public Sector Enterprises in India"- Management of Technological Change, Allied Publishers Limited, India.

[10] Machado. F.M(2001), “Aspects of Technology Management at the Industrial Enterprise Level " - Strengthening Technological Capability, Gyan Publishing House, New Delhi.

[11] Mashelkar.R.A(2001) “Five Technology Management Mantras for Indian Industry"-Proceedings of the 2001 National Seminar on Technology Management, Indian National Academy of Engineering.

[12] Mel Horwitch, "Accessing Innovative Capabilities: The Strategic Importance of Technology in Post-Modern Strategy"Management of Technological Change, Allied Publishers Limited, India.

[13] Millett, Stephen,M 1990 , ' The Strategic Management of Technologgical R\&D : International Journal of

[14] Technology Management, Vol.5, No.2.

[15] Nataranjan. R(2001), "The Nature and Scope of Technology Management" -Proceedings of the 2001 National Seminar on

[16] Technology Management, Indian National Academy of Engineering.

[17] Prasad.L(1995) “TechnologyManagement: SomePerspectives"-Management and labour studies, Vol.20, No.3, July1995.

[18] Sinha. P.K. "Management of Customer Satisfaction-A Case Study of Central Coalfields Limited"- Proceedings Marketing Summit-2000, BIT Mesra Ranchi.

[19] Tsang, E.W.K., 1995, The Implementation of Technology Transfer in Sino- foreign Joint Ventures. International Journal of

[20] Technology Management, 10,7/8, pp757-766

[21] Ulhoi, J. (1996). Towards a theoretical and methodological corporate technology management framework. The strategic

[22] perspective. International Journal of Technology Management. Vol. 12 No. 2.

[23] Dar.Usha(2003), "Management of Technological Change: Issues and Challenges" -Management of Technological Change, Allied Publishers Limited, India.

[24] V.K.Narayanan( 2002)“ Managing Technology and Innovation for competitive advantage”-Pearson education (Singapore) Pvt

[25] .Ltd, Delhi

[26] Virmani.B.R(2002)““ Technology Transfer and Human Resource Development”.-Strengthening Technological Capability,Gyan Publishing House, New Delhi.

Specific URLs:-

[27] ccl.gov.in/peo_crer/peo_car.htm

[28] http://www.iea.org/textbase/papers/2003/ciab_sustain.pdf

[29] http://www.atse.org.au/index.php

[30] en.wikipedia.org/wiki/Coal

[31] en.wikipedia.org/wiki/Coal_(poem)

[32] en.wikipedia.org/wiki/Coals 